\title{
PENGARUH PELAYANAN KESEHATAN GIGI DAN MULUT TERHADAP KEPUASAN PASIEN DI PUSKESMAS SENTOSA BARU KOTA MEDAN
}

\author{
Sri Astuti*, Mappeaty Nyorong, Neni Ekowati Januariana \\ Program Studi Kesehatan Masyarakat, Institut Kesehatan Helvetia. \\ *email: astuti95sri@gmail.com
}

\begin{abstract}
ABSTRAK
Mutu pelayanan kesehatan dapat memengaruhi derajat kesehatan dan kesejahteraan pasien, karena pasien yang merasa puas akan datang berobat kembali. Adapun tujuan dalam penelitian ini yaitu untuk menganalisis pengaruh pelayanan kesehatan gigi dan mulut terhadap kepuasan pasien di puskesmas Sentosa Baru Kota Medan. Penelitian ini menggunakan jenis penelitian kuantitatif survei analitik dengan rancangan cross sectional study. Lokasi penelitian ini dilakukan di puskesmas Sentosa Baru Kota Medan. Populasi penelitian yaitu seluruh pasien rawat jalan yang berkunjung dengan rata-rata kunjungan perbulan yaitu 422 pasien. Adapun jumlah sampel dalam penelitian ini sebanyak 81 orang. Teknik yang digunakan adalah purposive sampling. Data hasil survey dianalisis dengan menggunakan uji chi-square dan regeresi logistik. Hasil penelitian menunjukkan bahwa ada pengaruh wujud (tangible), kehandalan (reliability), cepat tanggap (responsiveness), kepastian (assurance) dan empati (emphaty) pelayanan kesehatan gigi dan mulut terhadap kepuasan pasien. Berdasarkan hasil penelitian diketahui bahwa wujud (tangible), kehandalan (reliability), cepat tanggap (responsiveness), (assurance) kepastian dan empati (emphaty) berpengaruh terhadap kepuasan pasien di puskesmas Sentosa Baru Kota Medan dan variabel yang paling berpengaruh terhadap kepuasan pasien adalah variabel cepat tanggap (responsiveness). Adapun saran bagi penelitian ini yaitu sebaiknya puskesmas untuk menjaga kepuasan pasien pelanggan dengan meningkatkan mutu pelayanan dan melengkapi sarana prasarana yang masih kurang sehingga kepuasan pasien terpenuhi dan pasien menjadi loyal.
\end{abstract}

\section{Kata Kunci : wujud (tangible), kehandalan (reliability), cepat tanggap (responsiveness), (assurance) kepastian dan empati (emphaty)}

\begin{abstract}
The quality of health services can affect the degree of health and well-being of patients, because satisfied patients will come for treatment again. The purpose of this study is to analyze the effect of dental and oral health services on patient satisfaction at the Sentosa Baru Public Health Center Medan City. This research uses a quantitative analytic survey research with cross sectional study design. The location of this study was conducted at the Sentosa Baru Public Health Center Medan City. The study population was all outpatients who visited with an average monthly visit of 422 patients. The number of samples in this study were 81 people. The technique used is purposive sampling. Survey data were analyzed using the chi-square test and logistic regression. The results showed that there was an effect of tangibility, reliability, responsiveness, assurance and empathy for dental and oral health services on patient satisfaction.Based on the results of the study note that tangible, reliability, responsiveness, assurance and empathy affect patient satisfaction at the Sentosa Baru Public Health Center in Medan and the variables that most influence on patient satisfaction are variables responsiveness. The suggestion for this research is that the Puskesmas should maintain customer satisfaction by increasing the quality of service and completing infrastructure that is still lacking so that patient satisfaction is fulfilled and patients become loyal.
\end{abstract}

Keywords : Tangible, Reliability, Responsiveness, Assurance And Empathy 


\section{Pendahuluan}

Sebagai salah satu fasilitas pelayanan kesehatan, Puskesmas memiliki peran yang sangat strategis dalam upaya mempercepat peningkatan derajat kesehatan masyarakat. Ketersediaan Puskesmas secara fisik, harus didukung dengan pelayanan prima dalam pemberian pelayanan kesehatan kepada masyarakat. Kualitas pelayanan di Puskesmas dalam hal ini merupakan salah satu faktor yang menjadi pertimbangan masyarakat dalam memilih suatu fasilitas kesehatan yang akan digunakannya apakah berkualitas atau tidak ${ }^{1}$

Pelayanan kesehatan yang berkualitas adalah pelayanan kesehatan yang dapat memuaskan setiap pemakai jasa pelayanan kesehatan sesuai dengan tingkat kepuasan rata-rata pasien serta yang penyelenggaraannya sesuai dengan standar dan kode etik profesi yang telah ditetapkan. Pihak Puskesmas perlu memberikan pelayanan sesuai dengan yang diharapkan pasien. Pasien selaku pengguna jasa pelayanan kesehatan di Puskesmas menuntut agar pelayanan yang berkualitas tidak hanya menyangkut kesembuhan dari penyakit secara fisik akan tetapi juga menyangkut terhadap sikap, pengetahuan dan keterampilan petugas dalam memberikan pelayanan serta tersedianya sarana dan prasarana yang memadai dan dapat memberikan kenyamanan ${ }^{2}$

Adapun dimensi kualitas pelayanan jasa yang dimaksud seperti : a) Tangible (wujud) yaitu segala sesuatu yang meliputi penampilan fisik dari layanan kesehatan seperti fasilitas, peralatan, dan alat-alat komunikasi petugas pelayanan; b) Reliability (kehandalan) yaitu segala sesuatu kemampuan petugas pelayanan untuk melaksanakan jasa yang telah dijanjikan secara konsisten dan dapat diandalkan, c) Responsiveness (cepat tanggap) yaitu kemauan petugas pelayanan untuk membantu dan menyediakan jasa/pelayanan yang cepat dan tepat, d) Assurance (kepastian) yaitu segala sesuatu yang mencakup pengetahuan dan keramah-tamahan petugas pelayanan dan kemampuan mereka untuk menimbulkan kepercayaan dan keyakinan, kesopanan dan sifat dapat dipercaya yang dimiliki para petugas pelayanan kesehatan, e) Empaty (empati) yaitu segala sesuatu pemahaman pemberian perhatian petugas pelayanan secara individual, kemudahan dalam melakukan komunikasi yang baik, dan memahami kebutuhan pasien ${ }^{3}$
Salah satu upaya pelayanan di Puskesmas yang sering dikunjungi masyarakat adalah pelayanan Kesehatan Gigi dan Mulut. Seseorang yang berkunjung ke pelayanan Kesehatan Gigi dan Mulut adalah orang yang memiliki penyakit gigi dan mulut. Seseorang dikatakan tidak sehat apabila tidak memiliki gigi dan mulut yang sehat.

Menurut Peraturan Menteri Kesehatan RI Nomor 89 Tahun 2015 tentang upaya kesehatan gigi dan mulut bahwa 1) Upaya Kesehatan Gigi dan Mulut dilaksanakan melalui Pelayanan Kesehatan Gigi dan Mulut perseorangan dan masyarakat, 2) Pelayanan Kesehatan Gigi dan Mulut sebagaimana dimaksud pada ayat 1 dilakukan untuk memelihara dan meningkatkan derajat kesehatan masyarakat dalam bentuk kegiatan peningkatan kesehatan gigi dan mulut, pencegahan penyakit gigi dan mulut, pengobatan penyakit gigi dan mulut, dan pemulihan kesehatan gigi dan mulut, 3) Pelayanan Kesehatan Gigi dan Mulut sebagaimana dimaksud pada ayat 1 dilakukan sesuai standar pelayanan, standar profesi, dan standar prosedur operasional, 4) Pelayanan Kesehatan Gigi dan Mulut sebagaimana dimaksud pada ayat 1 diselenggarakan oleh Pemerintah Pusat, Pemerintah Daerah, dan/atau masyarakat secara terpadu, terintegrasi dan berkesinambungan.

Berdasarkan data dari Dinas Kesehatan Kota Medan tahun 2018, diketahui bahwa sebanyak 89.047 kunjungan pada Pelayanan Kesehatan Gigi dan Mulut di seluruh Puskesmas yang ada di kota Medan, sedangkan untuk jumlah rujukan ada sebanyak 3.206. Adapun jumlah penyakit gigi terbanyak tahun 2018 yaitu penyakit pulpa dan jaringan periapikal ${ }^{4}$

Salah satu Puskesmas yang ada di Kota Medan yang terakreditasi madya adalah Puskesmas Sentosa Baru. Puskesmas Sentosa Baru Medan diharapkan mampu memberikan pelayanan kesehatan secara maksimal kepada masyarakat. Dengan memiliki sikap bertindak cepat dan tepat, berpihak kepada masyarakat, menegakkan kedisiplinan, menunjukkan transparansi, dan mewujudkan akuntabilitasnya.

Berdasarkan hasil survey awal yang dilakukan oleh peneliti di Puskesmas Sentosa Baru, diperoleh jumlah kunjungan dan rujukan ke Rumah Sakit selama 5 tahun terakhir, yaitu dari tahun 2014-2018. Dari tahun 2014-2015 mengalami peningkatan yaitu dari 2.019 kunjungan meningkat sebanyak 3.845 
kunjungan sehingga pada tahun 2015 jumlah kunjungan mencapai 5.864, namun meskipun demikian jumlah rujukan juga mengalami peningkatan yaitu dari 259 rujukan meningkat menjadi 265 rujukan. Pada tahun 2016 jumlah kunjungan mengalami penurunan sebanyak 100 kunjungan, sehingga jumlah kunjungannya hanya mencapai 5.758, akan tetapi jumlah rujukan terus meningkat menjadi 272 rujukan. Pada tahun 2017 jumlah kunjungan terus mengalami penurunan, yaitu sebanyak 624 kunjungan, akan tetapi jumlah rujukan meningkat menjadi 279 rujukan. Pada Tahun 2018, jumlah kunjungan mengalami penurunan angka yang signifikan dibandingkan tahun-tahun sebelumnya sebanyak 755 kunjungan. Jumlah kunjungan pada tahun 2018 hanya mencapai 4.379 sedangkan jumlah rujukan semakin meningkat, yaitu sebanyak 463 rujukan.

Jumlah pasien menurun dikarenakan keluarnya PERDA Nomor 7 Tahun 2016 tentang Retribusi Pelayanan Kesehatan yang isinya setiap warga kota Medan yang memiliki KTP tidak dipungut biaya di Puskesmas. Maka sejak berlakuknya Perda ini maka puskesmas tidak lagi melayani pasien dari seluruh wilayah dibatasi hanya melayani berdasarkan wilayah kerjanya.

Peneliti juga melakukan penelitian awal berupa pengambilan data survey kepuasan pasien berupa pengumpulan koin kepuasan pasien selama satu minggu di Bulan Oktober. Dari rekapitulasi kepuasan pasien dalam satu minggu didapatkan perincian sebanyak 28 koin

tidak puas, sedangkan sisanya 20 koin puas berikut
Tabel 1 Pengaruh Tangible (Wujud) Pelayanan Kesehatan Gigi Dan Mulut Terhadap Kepuasan Pasien di Puskesmas Sentosa Baru Kota Medan

\begin{tabular}{|c|c|c|c|c|c|c|c|}
\hline \multirow{3}{*}{ Tangible (Wujud) } & \multicolumn{6}{|c|}{ Kepuasan Pasien } & \multirow{2}{*}{$\begin{array}{c}p \\
\text { value }\end{array}$} \\
\hline & \multicolumn{2}{|c|}{ Kurang Puas } & \multicolumn{2}{|c|}{ Puas } & \multicolumn{2}{|c|}{ Total } & \\
\hline & $\mathbf{n}$ & $\%$ & $\mathbf{n}$ & $\%$ & $\mathbf{n}$ & $\%$ & \multirow{4}{*}{0,000} \\
\hline Kurang & 27 & 67,50 & 13 & 32,50 & 40 & 100 & \\
\hline Baik & 10 & 24,39 & 31 & 75,61 & 41 & 100 & \\
\hline Jumlah & 37 & 15,68 & 44 & 54,32 & 81 & 100 & \\
\hline \multicolumn{3}{|c|}{$\begin{array}{l}\text { Berdasarkan tabel } 1 \text { diketahui bahwa } \\
\text { dari } 81 \text { responden yang diteliti, sebagian besar } \\
\text { responden mengatakan bahwa alat yang } \\
\text { digunakan petugas kesehatan adalah baik } \\
\text { sebanyak } 41(50,62 \%) \text { responden. Dari } 41 \\
(50,62 \%) \text { responden tersebut, ada sebanyak } \\
10(24,39 \%) \text { responden mengatakan bahwa } \\
\text { alat yang digunakan petugas kesehatan } \\
\text { adalah baik dan kurang puas dengan pelayan }\end{array}$} & \multicolumn{5}{|c|}{$\begin{array}{l}\text { mengatakan mengatakan bahwa alat yang } \\
\text { digunakan petugas kesehatan adalah baik dan } \\
\text { puas dengan pelayanan. Berdasarkan hasil } \\
\text { perhitungan uji statistik diperoleh nilai p } \\
\text { significancy yaitu } 0,000<0,05 \text {, sehingga dapat } \\
\text { disimpulkan bahwa ada pengaruh wujud } \\
\text { (tangible) pelayanan kesehatan gigi dan mulut } \\
\text { terhadap kepuasan pasien di Puskesmas } \\
\text { Sentosa Baru Kota Medan. }\end{array}$} \\
\hline
\end{tabular}


Tabel 2 Pengaruh Reliability (Kehandalan) Pelayanan Kesehatan Gigi Dan Mulut Terhadap Kepuasan Pasien di Puskesmas Sentosa Baru Kota Medan

\begin{tabular}{|c|c|c|c|c|c|c|c|}
\hline \multirow{3}{*}{$\begin{array}{c}\text { Reliability } \\
\text { (Kehandalan) }\end{array}$} & \multicolumn{6}{|c|}{ Kepuasan Pasien } & \multirow{2}{*}{$\mathrm{p}$ value } \\
\hline & \multicolumn{2}{|c|}{ Kurang Puas } & \multicolumn{2}{|c|}{ Puas } & \multicolumn{2}{|c|}{ Total } & \\
\hline & $\mathbf{n}$ & $\%$ & $\mathbf{n}$ & $\%$ & $\mathbf{N}$ & $\%$ & \multirow{4}{*}{0,000} \\
\hline Kurang & 28 & 71,79 & 11 & 28,21 & 39 & 100 & \\
\hline Baik & 9 & 21,42 & 33 & 78,57 & 42 & 100 & \\
\hline Jumlah & 37 & 15,68 & 44 & 54,32 & 81 & 100 & \\
\hline
\end{tabular}

Hasil pengaruh menunjukkan bahwa sebagian besar responden mengatakan bahwa petugas kesehatan memiliki kehandalan yang baik sebanyak $42(51,85 \%)$ responden. Dari 42 $(51,85 \%)$ responden tersebut, ada sebanyak 9 $(21,42 \%)$ responden mengatakan bahwa petugas kesehatan memiliki kehandalan yang baik dan kurang puas dengan pelayan dan sebanyak $33(78,57 \%)$ responden mengatakan mengatakan bahwa petugas kesehatan memiliki kehandalan yang baik dan puas dengan pelayanan. Berdasarkan hasil perhitungan uji statistik diperoleh nilai $p$ significancy yaitu $0,000<0,05$, sehingga dapat disimpulkan bahwa ada pengaruh kehandalan (reliability) pelayanan kesehatan gigi dan mulut terhadap kepuasan pasien di Puskesmas Sentosa Baru Kota Medan

Tabel 3 Pengaruh Responsiveness (Cepat Tanggap) Pelayanan Kesehatan Gigi Dan Mulut Terhadap Kepuasan Pasien di Puskesmas Sentosa Baru Kota Medan

\begin{tabular}{|c|c|c|c|c|c|c|c|}
\hline \multirow{3}{*}{$\begin{array}{l}\text { Responsiveness } \\
\text { (Cepat Tanggap) }\end{array}$} & \multicolumn{6}{|c|}{ Kepuasan Pasien } & \multirow{2}{*}{ p value } \\
\hline & \multicolumn{2}{|c|}{ Kurang Puas } & \multicolumn{2}{|c|}{ Puas } & \multicolumn{2}{|c|}{ Total } & \\
\hline & $\mathbf{n}$ & $\%$ & $\mathbf{n}$ & $\%$ & $\mathbf{n}$ & $\%$ & \multirow{4}{*}{0,000} \\
\hline Kurang & 27 & 79,41 & 7 & 20,59 & 34 & 100 & \\
\hline Baik & 10 & 21,28 & 37 & 78,72 & 47 & 100 & \\
\hline Jumlah & 37 & 15,68 & 44 & 54,32 & 81 & 100 & \\
\hline
\end{tabular}

Berdasarkan tabel 3 diketahui bahwa dari 81 responden yang diteliti, sebagian besar responden mengatakan bahwa petugas kesehatan cepat tanggap dengan baik sebanyak $47(58,02 \%)$ responden. Dari 47 $(58,02 \%)$ responden tersebut, ada sebanyak $10(21,42 \%)$ responden mengatakan bahwa petugas kesehatan cepat tanggap dengan kategori baik dan kurang puas dengan pelayan dan sebanyak $37(7878,72 \%)$ responden

mengatakan mengatakan bahwa petugas kesehatan cepat tanggap dengan kategori baik dan puas dengan pelayanan. Berdasarkan hasil perhitungan uji statistik diperoleh nilai $p$ significancy yaitu $0,000<0,05$, sehingga dapat disimpulkan bahwa ada pengaruh cepat tanggap (responsiveness) pelayanan kesehatan gigi dan mulut terhadap kepuasan pasien di Puskesmas Sentosa Baru Kota Medan

Tabel 4 Pengaruh Assurance (Kepastian) Pelayanan Kesehatan Gigi Dan Mulut Terhadap Kepuasan Pasien di Puskesmas Sentosa Baru Kota Medan

\begin{tabular}{|c|c|c|c|c|c|c|c|}
\hline \multirow{3}{*}{$\begin{array}{c}\text { Assurance } \\
\text { (Kepastian) }\end{array}$} & \multicolumn{6}{|c|}{ Kepuasan Pasien } & \multirow[b]{2}{*}{ p value } \\
\hline & \multicolumn{2}{|c|}{ Kurang Puas } & \multicolumn{2}{|c|}{ Puas } & \multicolumn{2}{|c|}{ Total } & \\
\hline & $\mathbf{n}$ & $\%$ & $\mathbf{n}$ & $\%$ & $\mathbf{n}$ & $\%$ & \\
\hline Kurang & 27 & 69,32 & 12 & 30,77 & 39 & 100 & 0 \\
\hline Baik & 10 & 23,81 & 32 & 76,19 & 42 & 100 & 0,000 \\
\hline Jumlah & 37 & 15,68 & 44 & 54,32 & 81 & 100 & \\
\hline
\end{tabular}

Berdasarkan tabel 4diketahui bahwa dari 81 responden yang diteliti, sebagian besar responden mengatakan bahwa petugas kesehatan memberikan kepastian yang baik sebanyak $42(51,85 \%)$ responden. Dari 42 $(51,85 \%)$ responden tersebut, ada sebanyak $10(23,81 \%)$ responden mengatakan bahwa petugas kesehatan kepastian yang baik dan kurang puas dengan pelayan dan sebanyak 32 $(76,19 \%)$ responden mengatakan mengatakan bahwa petugas kesehatan memberikan kepastian yang baik dan puas dengan pelayanan. Berdasarkan hasil perhitungan uji statistik diperoleh nilai $p$ significancy yaitu $0,000<0,05$, sehingga dapat disimpulkan bahwa ada pengaruh kepastian (assurance) pelayanan kesehatan gigi dan mulut terhadap kepuasan pasien di Puskesmas Sentosa Baru Kota Medan. 
Tabel 5 Pengaruh Emphaty (Empati) Pelayanan Kesehatan Gigi dan Mulut Terhadap Kepuasan Pasien di Puskesmas Sentosa Baru Kota Medan

\begin{tabular}{|c|c|c|c|c|c|c|c|}
\hline \multirow{3}{*}{$\begin{array}{l}\text { Emphaty } \\
\text { (Empati) }\end{array}$} & \multicolumn{6}{|c|}{ Kepuasan Pasien } & \multirow{2}{*}{ p value } \\
\hline & \multicolumn{2}{|c|}{ Kurang Puas } & \multicolumn{2}{|c|}{ Puas } & \multicolumn{2}{|c|}{ Total } & \\
\hline & $\mathbf{n}$ & $\%$ & $\mathbf{n}$ & $\%$ & $\mathbf{n}$ & $\%$ & \multirow{4}{*}{0,009} \\
\hline Kurang & 25 & 59,52 & 17 & 40,48 & 42 & 100 & \\
\hline Baik & 12 & 30,78 & 27 & 67,22 & 39 & 100 & \\
\hline Jumlah & 37 & 15,68 & 44 & 54,32 & 81 & 100 & \\
\hline
\end{tabular}

Berdasarkan tabel 5 diketahui bahwa dari 81 responden yang diteliti, sebagian besar responden mengatakan bahwa petugas kesehatan memiliki empati yang kurang sebanyak 42 (51,85\%) responden. Dari 42 $(51,85 \%)$ responden tersebut, ada sebanyak $25(59,52 \%)$ responden mengatakan bahwa petugas kesehatan memiliki empati yang kurang dan kurang puas dengan pelayan dan sebanyak 17 (40,48\%) responden mengatakan mengatakan bahwa petugas kesehatan memiliki empati yang kurang dan puas dengan pelayanan. Berdasarkan hasil perhitungan uji statistik diperoleh nilai $p$ significancy yaitu $0,009<0,05$, sehingga dapat disimpulkan bahwa ada pengaruh (empati (emphaty) pelayanan kesehatan gigi dan mulut terhadap kepuasan pasien di Puskesmas Sentosa Baru Kota Medan.

\begin{tabular}{lcccc}
\multicolumn{1}{c}{ Variabel } & Tabel 6 Hasil Analisis Regresi Logistik & \\
\hline Tangible (Wujud) & B & P vlue & Exp(B)OR & 95\%Cl for Exp(B) \\
$\begin{array}{l}\text { Responsiveness (Cepat } \\
\text { Tanggap) }\end{array}$ & 2,329 & 0,001 & 10,265 & $2,649-39,77$ \\
& 3,045 & 0,000 & 21,006 & $5,343-82,580$ \\
\hline
\end{tabular}

Berdasarkan tabel 6 diatas dapat dilihat bahwa analisis regresi logistik menghasilkan satu variabel yang paling dominan berpengaruh terhadap kepuasan pasien di Puskesmas Sentosa Baru Kota Medan dengan $p$ value $<0,05$, yaitu variabel cepat tanggap (responsiveness) dengan signifikan 0,000 ( $p$ value $<0,05), \mathrm{OR}=21,006(95 \% \mathrm{Cl}=5,343-$ $82,580)$ artinya responden yang merasa cepat tanggap (responsiveness) baik dari pelayan kesehatan mempunyai peluang 21,006 kali tidak puas terhadap responden yang menyatakan kurang cepat tanggap (responsiveness) dari petugas kesehatan dengan nilai koefisien B yaitu 3,045 bernilai positif, maka semakin kurang cepat tanggap (responsiveness) dari petugas kesehatan semakin banyak pasien yang kurang puas dengan pelayanan kesehatan gigi dan mulut di Puskesmas Sentosa Baru Kota Medan.

\section{Pembahasan}

\section{Pengaruh Wujud (Tangible) Pelayanan Kesehatan Gigi dan Mulut terhadap Kepuasan Pasien di Puskesmas Sentosa Baru Kota Medan}

Aspek wujud atau penampilan fisik adalah suatu bukti langsung yang meliputi fasilitas fisik, perlengkapan dan peralatan yang digunakan oleh petugas kesehatan untuk tindakan medis. Wujud (tangible) petugas kesehatan yang dimaksud misalnya seperti selalu menggunakan seragam dengan rapi, bersih dan lengkap.

Berdasarkan hasil penelitian di ruang kesehatan gigi dan mulut Puskesmas Sentosa Baru Kota Medan diketahui bahwa dari 81 responden yang diteliti, sebagian besar responden menyatakan bahwa alat yang digunakan petugas kesehatan adalah baik sebanyak $41(50,62 \%)$ responden. Adapun alat-alat yang dimaksud yaitu dua unit gigi, lemari alat, peralatan pencabutan gigi dewasa terdiri dari: tang incisivus atas dewasa, tang molar 1 , tang molar 2 atas, tang molar 3 atas, tang radix atas, tang bein, tang being bengkok, tang incisivus bawah dewasa, tang molar bawah, tang radix bawah, tang premolar bawah, tang molar 3 bawah. Peralatan pencabutan gigi anak-anak terdiri dari : tang incisivus bawah, tang molar bawah, tang caninus bawah, tang incisivus atas, tang molar atas, tang caninus atas, tang radix atas, tang radix bawah. Spuit, gunting, kaca mulut, sonde, pincet, pengaduk semen, penghalus tulang rahang, plastis instrumen, nearbeken, alat sterilisator, sabun pencuci tangan, alat gigi dilakukan servis dan kalibrasi setiap tahunnya.

Selain itu ruangan kesehatan gigi dan mulut memiliki AC, ruangan tampak bersih dan harum karena dibersihkan dengan menggunakan pembersih lantai dan juga pengharum ruangan, dinding ruangan di cat dengan memilih warna menarik sehingga terlihat nyaman, lemari di dalam ruangan tidak 
mengahalangi cahaya. Hal ini telah sesuai dengan Permenkes nomor 75 tahun 2014 bahwa bangunan puskesmas harus mempunyai pencahayaan alami dan terdistribusi rata di ruangan.

Akan tetapi sebagian besar lainnya menyatakan tidak setuju bahwa ruang kesehatan gigi dan mulut memiliki gedung yang baik dan nyaman, karena ruangannya tidak terlalu besar, kursinya juga menggunakan kursi yang standar. Selain itu sebanyak $30 \quad(37,04 \%)$ responden yang menyatakan sangat tidak setuju ruang kesehatan gigi dan mulut terlihat bersih, hal ini disebabkan oleh keadaan responden yang datang berkunjung membandingkannya dengan klinik gigi swasta, sehingga ketika responden melihat ruangan kesehatan gigi dan mulut di Puskesmas Sentosa Baru mereka menilai kurang bersih dan kurang nyaman, Selain itu sebanyak 30 (37,04\%) responden yang menyatakan bahwa tidak setuju ruang kesehatan gigi dan mulut memiliki peralatan yang standard. Dalam hal peralatan di puskesmas memang belum sesuai dengan standard dari Permenkes nomor 75 tahun 2014 yang seharusnya memiliki peralatan seperti : jarum exterpasi, jarum K-file, skalpel, mata pisau bedah, pollishing bur dan lain-lain. Karena ketidaklengkapan alat di puskesmas dibandingkan dengan klinik gigi swasta sehingga responden yang terbiasa berobat ke klinik akan menyatakan bahwa tidak setuju ruang kesehatan gigi dan mulut memiliki peralatan yang standard.

Puskesmas Sentosa Baru belum memiliki alat rotgen foto gigi sebagai penunjang diagnose. Karena ketidaktersedian rotgen gigi di Puskesmas menyebabkan dokter gigi harus merujuk pasien ke rumah sakit untuk melihat kelainan penyakit gigi. Misalnya kista, abces, tumor, dan lain-lain. Belum memiliki alat perawatan saluran akar gigi (endodonti). Karena ketidaktersedian alat dan bahan perawatan saluran akar gigi (endodonti) tersebut menyebabkan dokter gigi harus merujuk pasien ke rumah sakit untuk perawatan selanjutnya.

Wujud (tangible) merupakan elemen yang sangat penting bagi pasien karena wujud (tangible) merupakan elemen yang langsung dapat dirasakan oleh pasien. Semakin baik persepsi pasien terhadap wujud (tangible) maka kepuasan pasien akan semakin tinggi. Dan jika persepsi pasien terhadap wujud (tangible) buruk, maka kepuasan pasien semakin rendah. Wujud (tangible) berhubungan positif terhadap kepuasan pasien. Kenyamanan berkaitan dengan pelayanan kesehatan yang tidak berhubungan langsung dengan efektifitas klinis, tetapi dapat memengaruhi kepuasan pasien dan bersedianya unutuk kembali ke fasilitas kesehatan untuk memperoleh pelayan berikutnya. Kenyamanan juga penting karena dapat memengaruhi kepercayaan pasien dalam pelayanan kesehatan. Kenyamanan berkaitan erat dengan lingkungan yang asri, kebersihan ruangan, kebersihan kamar mandi, kelengkapan ruangan, peralatan medis dan kebersihan makanan dan minuman. Kenyamanan merupakan faktor penting untuk menarik pasien yang dapat menjamin kelangsungan berobat dan kenyamanan suatu bentuk jasa yang tidak bisa dilihat dan diraba ${ }^{5}$

Kotler menyatakan bahwa wujud (tangible) pelayanan yaitu penampilan fasilitas fisik, peralatan dan berbagai materi komunikasi yang baik, menarik, berhubungan dengan tingkat kepuasan pasien. Wujud (tangible) petugas kesehatan adalah penampilan, baik berupa fisik maupun non fisik yang mampu merefleksikan kepercayaan diri dan kredibilitas dari pihak lain. Penampilan seseorang merupakan salah satu hal pertama yang diperhatikan selama komunikasi interpersonal. Kesan pertama timbul dalam 20 detik sampai 4 menit pertama dan $84 \%$ dari kesan terhadap seseorang berdasarkan penampilannya ${ }^{6}$

Dalam memberikan pelayanan setipa orang yang menginginkan pelayanan dapat merasakan pentingnya bukti fisik yang ditunjukkan oleh puskesmas, sehingga pelayanan yang diberikan memberikan kepuasan. Bentuk pelayanan bukti fisik biasanya berupa sarana dan prasarana pelayanan yang tersedia, teknologi pelayanan yang digunakan, performance pemberi pelayanan yang sesuai dengan karakteristik pelayanan yang diberikan dalam menunjukkan prestasi kerja yang dapat diberikan dalam bentuk pelayanan fisik yang dapat dlihat. Tidak dapat dipungkiri bahwa dalam suatu organisasi senantiasa mengutamakan bentuk kualitas, kondisi fisik yang dapat memberikan apresiasi terhadap orang yang memberi pelayanan.

Menurut asumsi peneliti untuk menciptakan perilaku pasien yang puas pada aspek wujud (tangible) di ruang kesehatan gigi dan mulut Puskesmas Sentosa Baru harus dijaga dan ditingkatkan kualitas pelayanan dari segi peralatan. Puskesmas Sentosa baru belum memiliki alat rontgen gigi sebagai penunjang diagnosa, karena ketidaktersediaan alat rontgen gigi di Puskesmas menyebabkan dokter gigi harus merujuk pasien ke rumah 
sakit untuk melihat kelainan penyakit gigi misalnya kista, abces, tumor, dan lainlain.Puskesmas juga belum memiliki alat perawatan saluran akar gigi (endodonti). Karena ketidaktersediaan alat dan bahan perawatan saluran akar gigi (endodonti) menyebabkan dokter gigi harus merujuk pasien ke rumah sakit untuk perawatan selanjutnya.

\section{Pengaruh Reliability (Kehandalan) Pelayanan Kesehatan Gigi dan Mulut terhadap Kepuasan Pasien di Puskesmas Sentosa Baru Kota Medan}

Aspek reliability (kehandalan) pelayanan yang akurat adalah berkaitan dengan kehandalan kemampuan petugas kesehatan di puskesmas untuk memberikan pelayanan segera, akurat sejak pertama kali pasien datang, tanpa membuat kesalahan apapun, serta memuaskan pasien sehingga pasien benar-benar yakin dengan kemampuan petugas kesehatan karena petugas kesehatan terkesan terampil, bertanggung jawab dan selalu menginformasikan tindakan petugas kesehatan yang akan dilakukan pada pasien, misalnya dengan menjelaskan fungsi tindakan kepada pasien ${ }^{7}$

Reliability (kehandalan) petugas kesehatan dalam memberikan pelayanan kepada pasien di puskesmas sentosa baru, dalam pelaksanaannya dimensi ini memuat dua unsur utama, yaitu kemampuan untuk memberikan pelayanan sebagaimana yang dijanjikannya dan keakuratan pelayanan yang diberikan atau seberapa jauh petugas kesehatan mampu meminimalisir/mencegah terjadinya kesalahan/error dalam proses pelayanan yang diberikan.

Menurut pengakuan pasien, tidak semua petugas kesehatan memberikan informasi dengan bahasa yang mudah di mengerti pasien karena kadang-kadang mereka menggunakan bahasa medis yang tidak dimengerti oleh pasien sehingga pasien tidak tahu apa yang dimaksud oleh petugas kesehatan tersebut, adapun pasien yang menyatakan petugas kesehatan sering menggunakan bahasa yang sulit dimengerti ada sebanyak 29 (35,80\%) reseponden, sedangkan responden yang setuju bahwa petugas kesehatan memberikan informasi dengan bahasa yang mudah di mengerti pasien yaitu dengan menggunakan bahasa Indonesia yang baik dan benar atau tidak menggunakan bahasa medis yang sulit dipahami oleh orang awam ada sebanyak 23 $(28,40 \%)$.
Menururt Parasuraman, kualitas pelayanan dibedakan menjadi dua yaitu kualitas teknikal dan kualitas fungsional. Kualitas teknikal merujuk pada kompetensi penyedia jasa untuk memberikan informasi yang dapat dipercaya dengan tingkat resiko yang dapat diterima sehingga membantu pasien untuk mencapai tujuannya. Pada penelitian ini harapan pasien terpenuhi terhadap kualitas teknikal maka mereka akan memiliki persepsi yang lebih besar terhadap kualitas teknikal (7). Menurut sebagain responden prosedur pelayanan di Ruang Kesehatan gigi dan mulut tidak berbelitbelit, misalnya mulai dari pendaftaran, penanganan sampai pengambilan obat pasien tidak mengalami kebingungan karena semua sudah di atur sesuai dengan SOP dan dibantu jelaskan oleh petugas kesehatan.

Penelitian Ahmad (2019) menyimpulkan bahwa reliability memiliki pengaruh terhadap kepuasan pasien. Hal ini berarti bahwa kualitas pelayanan yang dilihat dari reliability merupakan salah satu indikator bahwa pelayanan yang diberikan dengan tepat waktu, serta proses pemeriksaan, pengobatan dan perawatan dilakukan secara cepat, informasi yang diberikan juga jelas sehingga pasien merasa senang dan puas ${ }^{8}$

Responden di Puskesmas Sentosa baru juga menyatakan bahwa dokter gigi akan memberikan rujukan bila penyakitnya tidak dapat ditangani di Puskesmas, misalnya pasien yang memerlukan pembedahan maka akan dirujuk ke Rumah Sakit, Pasien yang memerlukan perawatan saluran akar gigi maka akan dirujuk kerumah sakit. Responden juga menyatakan bahwa petugas kesehatan memiliki kemampuan untuk menangani pasien secara tanggap, maka petugas kesehatan memberikan pelayanan yang cepat dan tepat serta memberikan informasi yang jelas terkait penyakit giginya dan memberikan edukasi kepada pasien. Petugas kesehatan mendapatkan pelatihan yang sesuai perkembangan teknologi dan ekspetasi masyarakat, seperti mengikuti seminar tentang perkembangan kesehatan gigi dan mulut baik seminar regional dan nasional. Petugas akan selalu cermat dalam menulis catatan rekam medis setiap pasien yang berkunjung.

Menurut Kotler dan Keller, reliability (kehandalan) pelayanan merupakan kemampuan untuk memberikan jasa sesuai dengan yang dijanjikan terpercaya, akurat, dan konsisten dan hal tersebut berhubungan dengan dengan tingkat kepuasan pasien. Reliability (kehandalan) petugas kesehatan adalah kehandalan petugas kesehatan dalam 
melayani pasien di puskesmas, seperti kecepatan dan ketepatan dalam memberikan pelayanan yang terbaik. Hal ini sangat penting karena apabila keluhan tersebut tidak segera ditanggapi maka akan timbul rasa tidak puas terhadap pelayanan. Reliability (kehandalan) petugas kesehatan yang kurang akan mengganggu pelayanan terhadap pasien

Berdasarkan hasil penelitian di Puskesmas Sentosa Baru menunjukkan bahwa sebagian pasien yang berkunjung di Puskesmas Sentosa Baru mengakui bahwa pelayanan kesehatan memenuhi kebutuhan yang dirasakannya dan diselenggarakan dengan cara yang sopan santun, tepat waktu, tanggap dan mampu menyembuhkan keluhannya serta mencegah berkembangnya atau meluasnya penyakit. Hal ini sangat penting karena pasien yang merasa puas akan mematuhi pengobatan dan mau datang berobat kembali dan menjadi konsumen yang loyal.

Menurut asumsi peneliti, kaitan dimensi pelayanan reliability (kehandalan) petugas kesehatan di ruang kesehatan gigi dan mulut Puskesmas Sentosa Baru merupakan suatu yang sangat penting dalam dinamika kerja suatu organisasi. Kehandalan merupakan bentuk ciri khas atau karakteristik dari pegawai yang memiliki prestasi tinggi. Kehandalan dalam pemberian pelayanan dapat terlihat dari kehandalan memberikan pelayanan yang sesuai dengan tingkat pengetahuan yang dimiliki, kehandalan dalam terampil menguasai bidang kerja yang diterapkan, kehandalan dalam penguasaan bidang kerja sesuai pengalaman kerja yang ditunjukkan dan kehandalan menggunakan teknologi kerja.

Dalam meningkatkan Reliability (kehandalan) petugas kesehatan di ruang kesehatan gigi dan mulut Puskesmas Sentosa Baru dengan cara dilakukan pendidikan dan pelatihan kepada petugas kesehatan secara berkesinambungan sehingga mereka menjadi petugas kesehatan yang benar-benar mampu memberikan pelayanan yang handal (zero defect/ free error) sekaligus memiliki kesadaran yang tinggi akan pentingnya pelayanan yang reliable. Selain itu, institusi juga perlu menyediakan infrastruktur yang menunjang program free error. Dalam seting pelayanan puskesmas, pelayanan yang reliabel berarti pelayanan yang bebas dari kesalahan pengkajian, diagnosa, maupun penanganan, tidak terjadi malpraktik, dan pelayanan yang diberikan memberikan jaminan perbaikan kondisi pasien yang berobat.
Hasil dari kuesioner menyatakan bahwa prosedur pelayanan di ruang kesehatan gigi dan mulut berbelit-belit. Hal ini disebabkan sebelum dilakukan tindakan pencabutan gigi pasien wajib dilakukan pemeriksaan fisik seperti pengukuran tinggi badan, berat badan, pemeriksaan tekanan darah serta dilakukan pemeriksaan penunjang seperti pemeriksaan kadar gula darah. Semua pemeriksaan ini dilakukan agar pasien safety. Namun pasien merasa tindakan tersebut berbelit-belit.

\section{Pengaruh Responsiveness (Cepat Tanggap) Pelayanan Kesehatan Gigi Dan Mulut Terhadap Kepuasan Pasien di Puskesmas Sentosa Baru Kota Medan}

Aspek kemampuan pelayanan yang akurat adalah berkaitan dengan responsiveness (cepat tanggap) petugas kesehatan di puskesmas untuk memberikan pelayanan segera, akurat sejak pertama kali pasien datang, tanpa membuat kesalahan apapun, serta memuaskan pasien sehingga pasien benar-benar yakin dengan kemampuan petugas kesehatan karena petugas kesehatan terkesan baik, terampil, bertanggung jawab dan selalu menginformasikan tindakan petugas kesehatanan yang akan dilakukan pada pasien, misalnya dengan menjelaskan fungsi tindakan kepada pasien.

Berdasarkan hasil penelitian menunjukkan bahwa dari 81 responden yang diteliti, sebagian besar responden mengatakan bahwa petugas kesehatan cepat tanggap dengan baik sebanyak $47(58,02 \%)$ responden. Dari 47 $(58,02 \%)$ responden tersebut, ada sebanyak $10(21,42 \%)$ responden menyatakan bahwa petugas kesehatan cepat tanggap dengan kategori baik dan kurang puas dengan pelayan. Meskipun petugas kesehatan cepat tanggap dalam melakukan pelayanan namun tidak semua responden merasa puas dengan hal itu, karena meskipun petugas cepat tanggap namun responden menilai petugas kurang ramah terhadap responden sehingga responden merasa kurang dihargai pada saat melakukan kunjungan. Ketanggapan petugas untuk membantu pasien dan memberikan jasa dengan cepat serta mendengar dan mengatasi keluhan dari pasien dan hal tersebut berhubungan dengan tingkat kepuasan pasien di ruang kesehatan gigi dan mulut

Hal tersebut sejalan dengan penelitian Parrasuraman bahwa untuk dunia kesehatan, menuju kepuasan pasien petugas kesehatan bersedia mendengarkan keluhan, tidak membiarkan pasien menunggu, serta sebagai petugas kesehatan adalah tenaga professional 
yang seharusnya mudah diakses oleh pasien. Membiarkan pasien menunggu tanpa adanya suatu alasan yang jelas dapat menyebabkan persepsi yang negative dalam kualitas pelayanan.

Harapan pasien terhadap responsiveness (cepat tanggap) pelayanan hampir dapat dipastikan berubah dengan kecenderungan naik dari waktu ke waktu. Faktor komunikasi dan situasi fisik disekeliling pasien yang menerima pelayanan mempengaruhi penilaian pasien. Komunikasi kepada pasien mengenai proses pelayanan yang diberikan akan membentuk persepsi yang lebih positif, salah satunya adalah kesigapan dan ketulusan dalam menjawab pertanyaan dan permintaan pasien.

Berdasarkan hasil observasi peneliti di ruang kesehatan gigi dan mulut di puskesmas Sentosa Baru tentang responsiveness (cepat tanggap) ditemukan kurang tanggapnya petugas kesehatan dan belum sesuai harapan responden. Dapat dilihat dari distribusi frekuensi jawaban responden tentang ketanggapan menunjukkan hampir semua pertanyaan sebagian besar responden menjawab kurang memuaskan. Pasien mengeluh lama mengantri untuk mendapatkan tindakan medis di ruang kesehatan gigi dan mulut. Hal ini disebabkan karena tindakan medis yang dilakukan untuk satu orang pasien gigi membutuhkan waktu minimal 20 menit dalam menyelesaikan tindakan. Apabila tindakan pencabutan yang sulit maka membutuhkan waktu lebih dari 30 menit. Sedangkan pasien lainnya kurang sabar menunggu untuk mendapatkan tindakan medisnya.

Menurut asumsi peneliti, responsiveness (cepat tanggap) berhubungan dengan kepuasan pasien di ruang kesehatan gigi dan mulut di puskesmas Sentosa Baru. Ketanggapan petugas kesehatan saat bertugas harus terus ditingkatkan karena petugas kesehatan kurang cepat dalam melayani permintaan medis dan menanggapi keluhan pasien. Adanya kepuasan yang dirasakan pasien membuat mereka memutuskan untuk tetap menggunakan jasa pelayan di ruang kesehatan gigi dan mulut di puskesmas Sentosa Baru.

\section{Pengaruh Assurance (Kepastian) Pelayanan Kesehatan Gigi dan Mulut Terhadap Kepuasan Pasien di Puskesmas Sentosa Baru Kota Medan}

Aspek assurance (kepastian) adalah mencakup menjamin keamanan, kesopanan, mampu menumbuhkan kepercayaan pasiennya. Kepastian juga berarti bahwa bebas bahaya, resiko dan keragu-raguan. Dalam hal ini, petugas kesehatan diharapkan bisa memberikan garansi bahwa ketika pasien ditangannya, maka kesembuhanlah yang akan didapat, dengan menumbuhkan kepercayaan pasien, bahwa mereka di tangan yang tepat sehingga pasien yakin akan pilihannya dalam menyembuhkan penyakit yang dideritanya ${ }^{9}$

Berdasarkan hasil jawaban responden diketahui bahwa banyak responden yang menyatakan ada jaminan privasi selama pemeriksaan atau konsultasi, ruang kesehatan gigi dan mulut menyediakan Petugas kesehatan yang terampil, Ruang kesehatan gigi dan mulut menyediakan petugas kesehatan yang memiliki cara kerja yang baik, Petugas kesehatan memiliki tanggung jawab penuh dalam melaksanakan tugas, Petugas kesehatan di ruang kesehatan gigi dan mulut tidak membeda-bedakan pasien, Petugas kesehatan memiliki pengetahuan yang baik terkait masalah gigi dan mulut, Ruang kesehatan gigi dan mulut menyediakan Petugas kesehatan yang berkualitas, Dokter gigi di Ruang kesehatan gigi dan mulut merupakan tamatan S1 Kedokteran gigi, Perawat gigi di Ruang kesehatan gigi dan mulut merupakan tamatan D3 Keperawatan, Ruang kesehatan gigi dan mulut menerima pasien BPJS dan pasien umum

Assurance (kepastian) yang dimaksud dalam penelitian ini merupakan pengetahuan petugas kesehatan terhadap jasa secara tepat, kesopansantunan petugas dalam memberi pelayanan, ketrampilan dalam memberikan informasi, kemampuan dalam memberikan keamanan dan kemampuan dalam menanamkan kepercayaan dan keyakinan pasien terhadap puskesmas. Pengetahuan, kesopansantunan, dan kemampuan para petugas kesehatan di puskesmas dapat menumbuhkan rasa percaya para pasien kepada puskesmas. Petugas kesehatan yang memiliki pengetahuan yang luas sehingga dapat menjawab pertanyaan dari pasien. Kepastian yang mencakup pengetahuan dan keterampilan petugas kesehatan ${ }^{10}$

Penelitian ini sejalan dengan penelitian yang dilakukan oleh Aulia, dkk (2017) Hasil penelitian menunjukkan bahwa kualitas 
pelayanan kesehatan mulut yang terdiri dari dimensi tangible, realiability, responsiveness, assurance dan emphaty berpengaruh signifikan terhadap pasien $(p<0,05)$. Kualitas layanan yang lebih baik akan meningkatkan kepuasan pasien. Pasien yang lebih puas dalam menerima layanan dapat memotivasi mereka untuk mengunjungi kembali dan menggunakan kembali layanan kesehatan ${ }^{11}$

Kotler menyatakan bahwa assurance (kepastian) pelayanan yaitu kemampuan petugas kesehatan untuk menimbulkan keyakinan dan kepercayaan terhadap janji yang telah dikemukakan kepada konsumen, dan hal tersebut berhubungan dengan tingkat kepuasan pasien. Demi meningkatkan kualitas pelayanan dan menjaga keselamatan pasien, Puskesmas menerapkan "pasien safety" dalam melaksanakan pelayanannya sehingga pasien yang masuk akan merasa aman

Menurut asumsi peneliti, jaminan atas pelayanan yang diberikan oleh petugas kesehatan sangat ditentukan oleh performance atau kinerja pelayanan, sehingga diyakini bahwa petugas kesehatan tersebut mampu memberikan palayanan yang handal, mandiri dan profesional dan berdampak pada kepuasan pelayanan yang diterima. Selain dari performance tersebut jaminan dari suatu pelayanan juga ditentukan dari adanya komitmen organisasi yang kuat yang menganjurkan agar, setiap petugas kesehatan memberikan pelayanan secara serius dan sungguh-sungguh untuk memuaskan orang yang dilayani. Bentuk jaminan yang lain yaitu jaminan terhadap pegawai yang memiliki perilaku, kepribadian (personality Behaviour) yang baik dalam memberikan pelayanan tentu akan berbeda dengan petugas kesehatan yang memiliki watak atau karakter yang kurang baik dalam memberikan pelayanan

Baik atau buruknya kualitas Puskesmas Sentosa Baru tergantung kepada kemampuan puskesmas dalam memenuhi harapan pasien secara konsisten. Selain itu, citra kualitas yang baik bukanlah berdasarkan sudut pandang Puskesmas Sentosa Baru tetapi harus dilihat dari sudut pandang atau persepsi seluruh pengunjung. Assurance (kepastian) dalam penelitian ini berhubungan dengan kepuasan pasien pengguna, akan tetapi dengan mutu pelayanan yang disajikan baik oleh puskesmas membuat pasien tetap mau mengikuti anjuran rujukan dan tidak meminta untuk pindah rujuk ke fasilitas kesehatan lainnya.

Adapun komplain pasien tentang kepastian terhadap pelayanan ruang kesehatan gigi dan mulut diantaranya: pasien mengeluh merasa tidak puas karena sewaktu berobat di ruang kesehatan gigi dan mulut pecabutan gigi ditunda. Hal ini tindakan pencabutan gigi dilakukan setelah infeksi penyakit gigi benar benar hilang sesuai dengan prosedur medis gigi yang sudah tetap, maka dari itu dibutuhkan waktu untuk pengobatan terlebih dahulu baru kemudian bisa dilakukan tindakan cabut gigi, hal seperti ini yang dirasakan pasien jadi pasien merasa tindakan cabut giginya ditunda-tunda.

\section{Pengaruh Emphaty (Empati) Pelayanan Kesehatan Gigi dan Mulut Terhadap Kepuasan Pasien di Puskesmas Sentosa Baru Kota Medan}

Aspek emphaty (empati) adalah kemudahan dalam melakukan hubungan komunikasi yang baik, perhatian pribadi dan memahami kebutuhan pasien sebagai pelanggan dan bertindak demi kepentingan pasien. Petugas kesehatan diharapkan bisa memahami kesulitan-kesulitan pribadi masingmasing pasien dan membantu mereka keluar dari kesulitannya. Pasien akan merasa diperhatikan oleh petugas kesehatan jika apa yang dibutuhkan dan dikeluhkannya ditanggapi secara baik oleh pihak petugas kesehatan, dan sikap yang tulus dan berifat individual atau pribadi yang diberikan petugas kesehatan kepada pasien seperti kemudahan untuk menghubungi petugas kesehatan, kemampuan petugas kesehatan untuk berkomunikasi dengan pasien dan keluarga pasien. Semakin baik persepsi petugas kesehatan terhadap kepedulian (empathy) maka kepuasan pasien akan semakin tinggi. Dan jika persepsi pasien terhadap kepedulian (empathy) buruk, maka kepuasan pasien akan semakin rendah. .

Hasil penelitian ini sejalan dengan penelitian Warwuru (2017), tentang hubungan antara petugas layanan dengan kepuasan pasien, hasil penelitian tentang petugas menunjukkan hasil $62,5 \%$ yang pada umumnya berada dalam kategori baik. Berdasarkan hasil analisis uji chi-square didapatkan hasil dengan nilai $p=0,000<\alpha=0,05$ yang berarti ada hubungan antara petugas dengan kepuasan pasien. Pelayanan petugas dinilai baik karena petugas dalam pelayanannya mampu berkomunikasi dengan baik dan sopan dalam memberikan pelayanan, dokter yang merawat memiliki kemampuan yang baik, petugas kesehatan terampil dalam melakukan pekerjaanya dan petugas farmasi memberikan penjelasan yang baik tentang obat yang harus dikonsumsi responden. Petugas di RSUP Prof. Dr. R. D Kandou 
Manado memiliki tanggung jawab yang tinggi dalam memberikan pelayanan ${ }^{12}$

Pasien yang merasa puas akan kembali lagi memanfaatkan pelayanan puskesmas jika mereka membutuhkannya lagi dan berpendapat bahwa petugas kesehatan memiliki kontribusi yang unik terhadap kepuasan pasien dan keluarganya. Pelayanan dan perilaku petugas kesehatan merupakan faktor yang sangat berhubungan terhadap kepuasan pasien. Peningkatan prioritas kepuasan pasien adalah memperbaiki kualitas pelayanan dengan mendistribusikan pelayanan yang adil, ramah dan sopan.

Menurut asumsi peneliti, empati dalam suatu pelayanan adalah adanya sutau perhatian, keseriusan, pengertian dan keterlibatan pihak-pihak yang berkepentingan dengan pelayanan untuk mengembangkan dan melakukan aktifitas pelayanan sesuatu dengan tingkat pengertian dan pemahaman dari masing-masing pihak tersebut. Pihak yang memberikan pelayanan harus memiliki empati memahami masalah dari pihak yang ingin dilayani. Pihak yang dilayani seyogyanya memahami keterbatasan dan kemampuan orang yang melayani. Sehinga keterpaduan antara pihak yang melayani dan mendapat pelayanan memiliki perasaan yang sama. Berarti dalam suatu organisasi kerja menjadi sangat penting dalam memberikan suatu kualitas pelayanan sesuai prestasi kerja yang ditunjukkan oleh seorang petugas kesehatan. Empati tersebut mempunyai inti yaitu mampu memahami orang yang dilayani dengan penuh perhatian, keseriusan, simpatik, pengertian dann adanya keterlibatan dalam berbagai permasalahan yang dihadapi orang yang dilayani.

Hal yang membedakan Puskesmas Sentosa Baru dengan puskesmas lainnya adalah menanamkan tata nilai puskesmas SENTOSA kepada seluruh petugas kesehatan yaitu Senyum, sapa, salam, sopan, dan santun; Empati; Nyaman; Terampil dan terlatih; Optimis; Sederhana; dan Akuntabel. Sentuhan psikologis yang bisa disampaikan petugas kesehatan, dan tim medis lainnya kepada pasien akan mengurangi stress yang dialaminya pada masa sakit, dan ternyata kelelahan psikis berkontribusi terhadap penyakit yang diderita pasien semakin parah. Motivasi dari tim medis bisa menurunkan kecemasan dengan memberikan dukungandukungan emosional berupa kesabaran, perhatian, motivasi supaya pasien akan sembuh lebih cepat.
Berdasarkan hasil penelitian ditemukan bahwa responden yang berjenis kelamin perumpuan lebih banyak dari pada responden laki-laki, adapun faktor yang menyebabkan perbedaan tersebut adalah dari jumlah penduduk Indonesia lebih banyak perempuan dari pada laki-laki, didukung oleh lokasi Puskesmas yang berdekatan dengan pajak. Rata-rata pengunjung dan penjual di pajak mayoritas perempuan.

Berdasarkan hasil observasi dari data pasien ditemukan bahwa pasien yang berulang berobat lebih banyak dibandingkan dengan pasien baru. Menurut asumsi peneliti hal ini terjadi karena ada kebijakan BPJS bahwa setiap pasien peserta BPJS wajib berobat di fasilitas kesehatan tingkat satu yang sudah ditetapkan berdasarkan wilayah tempat tinggalnya. Tindakan-tindakan yang berhubungan dengan pencabutan gigi, penambalan gigi, dan lain-lain dilakukan di Puskesmas dan apabila ada kasus pembedahan, perawatan saluran akar gigi, dan kasus yang lain maka akan dirujuk ke rumah sakit.

\section{Kesimpulan}

Berdasarkan hasil penelitian yang telah dilakukan dapat disimpulkan sebagai berikut: Ada pengaruh wujud (tangible) pelayanan kesehatan gigi dan mulut terhadap kepuasan pasien di Puskesmas Sentosa Baru Kota Medan. Ada pengaruh kehandalan (reliability) pelayanan kesehatan gigi dan mulut terhadap kepuasan pasien di Puskesmas Sentosa Baru Kota Medan. Ada pengaruh cepat tanggap (responsiveness) pelayanan kesehatan gigi dan mulut terhadap kepuasan pasien di Puskesmas Sentosa Baru Kota Medan. Ada pengaruh kepastian (assurance) pelayanan kesehatan gigi dan mulut terhadap kepuasan pasien di Puskesmas Sentosa Baru Kota Medan. Ada pengaruh empati (emphaty) pelayanan kesehatan gigi dan mulut terhadap kepuasan pasien di Puskesmas Sentosa Baru Kota Medan. Adapun variabel yang paling berpengaruh terhadap kepuasan pasien di Puskesmas Sentosa Baru adalah variabel cepat tanggap (responsiveness). Disarankan bagi petugas kesehatan untuk menjaga kepuasan pasien dengan meningkatkan kualitas pelayanan gigi dan mulut dengan cara peningkatan kompetensi dengan melakukan seminar regional dan nasional. Selain itu dengan meningkatkan responsiveness yang baik dengan melakukan pelayanan secara cepat dan tepat, merespon keluhan dengan cepat, meningkatkan kehandalan dari petugas kesehatan. 


\section{Daftar Pustaka}

Depkes RI. (2008). Pedoman Kerja Puskesmas. Direktorat Jenderal Pembinaan Kesehatan Masyarakat, Depkes RI, Jakarta.

Kurniawan A. (2005). Transformasi Pelayanan Puskesmas. Jakarta: Ghalia Indonesia.; 2005.

Parasuraman A, Zeithaml VA, Berry LL. (1985). Problems and strategies in services marketing. Jurnal Marketing. Sage Publications Sage CA: Los Angeles, CA; 49(2):33-46.

Dinas Kesehatan Kota Medan. (2019). Profil Kesehatan Kota Medan Tahun 2019.

Rif'adarajad S, Sarita B, Balaka MY. (2017). Faktor-Faktor Yang Berpengaruh Pada Loyalitas Pengguna Rawat Inap Rumah Sakit Umum Daerah Kabupaten Buton. Jurnal Progam Ekonomi Pembangunan. 1(2):56-64

Kotler P, Keller KL. (2007). Alih Bahasa: Benyamin Molan. 2005. Manajemen Pemasaran Ed Kesebelas Jilid. 2.
Rust RT, Oliver L. Richard, SerQual. (1994). New Direction Theory and Practice. Sage Publication. Inc. USA; 1994.

Ahmad, Fatimah. (2019). Pengaruh Persepsi Mutu Pelayanan Terhadap Tingkat Kepuasan Pasien Di Puskesmas Titi Papan Kecamatan Medan Deli Tahun 2019. PhD Thesis. Universitas islam Negeri Sumatera Utara

Zonitch, Barbara Anne. (2012) Familiar Violence: Gender And Social Upheaval In The Novels Of Frances Burney.

Reichheld, Frederick F. (2004). Loyalty And The Renaissance Of Marketing. Marketing Management, 2004, 2.4: 10.

Aulia R, Adhani R, Taufiqurrahman I, Hatta I. (2017). Pengaruh Kualitas Pelayanan Kesehatan Gigi dan Mulut Terhadap Kepuasan Pasien BPJS di Layanan Primer Banjarmasin. Dentino. 2(1):95100.

Waruwu, Ariful Hakim. (2017). Perlindungan Hukum Terhadap Pasien Peserta JKN BPJS Kesehatan dalam Perjanjian Kerjasama Antara RSUD Gunungsitoli dengan BPJS Kesehatan Cabang Gunungsitoli. 